\title{
A JURISPRUDÊNCIA DOS TRIBUNAIS SUPERIORES E O DIREITO À SAÚDE - EVOLUÇÃO RUMO À RACIONALIDADE
}

Jurisprudence in Brazilian Superior Courts and the right to health - progress toward rationality

${ }^{1}$ Pontifícia Universidade Católica de Goiás. Goiânia/GO, Brasil.

${ }^{2}$ Ministério Público Federal. Rio Verde/GO, Brasil.

Correspondência: Otávio Balestra Neto. E-mail: balestraneto@msn.com.

Recebido em: 09/02/2014. Revisado em: 17/11/2014. Aprovado em: 05/12/2014. 


\section{RESUMO}

O direito à saúde tem sido objeto de intensa judicialização no Brasil, com um número crescente de ações ano a ano. Este cenário tem gerado debates acerca do alcance deste inquestionável direito fundamental e suas repercussões na administração judiciária e nos orçamentos públicos. O presente trabalho estuda a posição adotada pelo Supremo Tribunal Federal e pelo Superior Tribunal de Justiça acerca do direito à saúde, mediante análise da jurisprudência das duas cortes, classificando-a em fases distintas segundo critério material e cronológico. Em um primeiro momento, a jurisprudência negou a viabilidade judicial do direito à saúde. Depois, passou-se a uma etapa na qual o acesso às prestações materiais em saúde foi entendido praticamente como ilimitado. Atualmente, prevalece uma posição conciliadora entre as inadiáveis necessidades do cidadão em saúde pública e a observância da racionalidade das políticas públicas sanitárias, sem embargo da flexibilidade cabível em casos específicos.

\section{Palavras-Chave}

Direito à Saúde; Judicialização; Jurisprudência.

\section{ABSTRACT}

The right to health has been an object of intense court action in Brazil, with a growing number of lawsuits each year. This situation has led to debates on the reach of this fundamental and unalienable right, in addition to its repercussions in judiciary administration and public budgets. The current study examines the positions adopted by the Brazilian Federal Supreme Court and the Brazilian Superior Court in regard to the right to health. The paper includes an analysis of the jurisprudence of the two courts and classifies it into distinct phases according to material and chronological criteria. First, jurisprudence denied the judicial viability of the right to health. Later, it became a step in which access to material benefits involved in healthcare became understood as essentially unlimited. Currently, a conciliatory stance prevails between the urgent needs of the citizen in the public health system and observance of the rationality of public health policies, with some flexibility in specific cases.

\section{Keywords}

Judicialization; Jurisprudence; Right to Health. 


\section{Introdução}

A crescente judicialização do direito à saúde é objeto de especial atenção dos órgãos de cúpula do Poder Judiciário brasileiro, seja pela novidade da temática, seja por sua complexidade técnica - que envolve questões nas quais a mera aplicação do direito positivo esbarra em situações existenciais extremas, ligadas à medicina e a outras ciências da saúde -, seja porque o próprio ramo do direito que trata da matéria - o Direito Sanitário - ainda se encontra em franco desenvolvimento doutrinário.

Além disso, a judicialização da saúde pública também suscita debates acerca da possível interferência do Poder Judiciário nas políticas públicas sanitárias, cuja execução afeta o Poder Executivo, gerando discussões teóricas sobre os limites do ativismo judicial no Brasil e o princípio constitucional da separação dos poderes ${ }^{1}$.

Cada uma dessas variáveis é considerada ora com maior peso, ora com menos relevância, pela jurisprudência dos tribunais superiores. Este trabalho dedica-se a analisar a evolução histórica da jurisprudência do Supremo Tribunal Federal (STF) e do Superior Tribunal de Justiça (STJ) no tocante ao direito à saúde, demonstrando que a interpretação dessas cortes acerca do tema passou por três fases distintas. No momento atual, nota-se que a posição jurisprudencial dominante firma-se no sentido de um equilíbrio possível entre as infinitas necessidades de prestações materiais de saúde aos cidadãos, principalmente os mais carentes, e a observância das políticas públicas sanitárias delineadas pelo Estado brasileiro.

A judicialização ${ }^{2}$ da saúde no Brasil é um fenômeno recente, típico do cenário jurídico instalado pela Constituição Federal de 1988 e, também, pelos níveis de inclusão social construídos no país nas últimas décadas, propiciando situações formais e materiais de maior participação da cidadania na gestão de seu cotidiano ${ }^{3}$.

De fato, sob o regime constitucional atual, passou-se a reconhecer que o Poder Judiciário, quando provocado adequadamente, é um poderoso instrumento

\footnotetext{
1“Para que criemos um novo paradigma para a aplicação e a garantia do direito à saúde, é preciso crescer na intersecção entre os saberes e as práticas profissionais de operadores do direito, médicos e gestores públicos de saúde, inclusive na participação da sociedade civil em todo esse processo. É preciso que o direito se dirija para além do processo judicial e se insira, com sua especificidade técnico-jurídica, nas questões que envolvem a área sanitária, em seus âmbitos técnicos e políticos". (DELDUQUE, Maria Célia; MARQUES, Sílvia Badim; CIARLINI, Álvaro. Judicialização das políticas públicas de saúde no Brasil. In: ALVES, Sandra Mara Campos; Dedulque, Maria Célia; Dino Neto, Nicolau (Orgs.). Direito sanitário em perspectiva. Brasília: ESMPU: Fiocruz, 2013. v. 2, p. 211).

2“A justiciabilidade ou acionabilidade nada mais é do que a possibilidade de buscar a concretização e o respeito de um direito por meio do Poder Judiciário, ou seja, é a possibilidade de utilização de mecanismos jurídicos para conferir-lhe efetividade". (SALAZAR, Andrea Lazzarini; GROU, Karina Bozola. A defesa da saúde em juízo: teoria e prática. São Paulo: Verbatim, 2009. p. 13).

${ }^{3}$ LEAL, Rogério Gesta. Condições e possibilidades eficaciais dos direitos fundamentais sociais: os desafios do Poder Judiciário no Brasil. Porto Alegre: Livraria do Advogado, 2009. p. 82.
} 
de formação de políticas públicas. Exemplo disso certamente é o caso da previdência social brasileira, uma vez que, não fosse a atitude dos cidadãos reivindicarem judicialmente e em massa seus direitos, as políticas públicas previdenciárias estariam mais ou menos onde sempre estiveram ${ }^{4}$.

As primeiras ações que discutiam o direito à saúde chegaram às cortes superiores em meados da década de $1990^{5}$, demandando basicamente o direito de acesso ao fornecimento de medicamentos pelo poder público. Desde então, e principalmente a partir do início dos anos 2000, o número de ações judiciais relacionadas ao direito à saúde cresceu exponencialmente.

O último levantamento do Conselho Nacional de Justiça (CNJ) revelou que, em setembro de 2010, tramitavam nas várias instâncias do Poder Judiciário estadual e federal - um total de 240.890 ações, sem contar os dados dos tribunais dos Estados do Amazonas, Paraíba e Pernambuco, que não enviaram informações ${ }^{6}$.

Por tratar de questões muitas vezes dramáticas, com inadiável necessidade de tutela jurisdicional por meio de decisões liminares, várias dessas ações chegaram ao STF pela via da suspensão de liminar7.

Em razão da aguda importância do tema, em 5 de março de $2009^{8}$, o STF convocou audiência pública ${ }^{9}$ com diversos segmentos da sociedade civil, a fim de

${ }^{4}$ LOPES, José Reinaldo de Lima. O direito subjetivo e direitos sociais: o dilema do Judiciário no Estado Social de Direito. In FARIA, José Eduardo (Org.). Direitos humanos, direitos sociais e justiça. São Paulo: Malheiros Ed., 2010. p. 136.

${ }^{5}$ É interessante a reflexão de Gustavo Amaral sobre o tema: "Parece relativamente claro que na passagem da primeira para a segunda década do século XXI a prática judicial acerca do chamado 'direito à saúde' busca uma transição. Talvez em momentos já remotos, bem antes de meados dos anos 90 do século anterior, a matéria tenha sido restrita ao que o Estado se dispõe a dar. De meados dos anos 90 em diante, seguramente, se viu o predomínio de decisões que extremavam um conflito em abstrato entre 'a inviolabilidade do direito à vida e à saúde, que se qualifica como um direito subjetivo inalienável assegurado a todos pela própria Constituição da República, ou fazer prevalecer, contra esta prerrogativa fundamental, um interesse financeiro secundário do Estado'”. (AMARAL, Gustavo. Saúde direito de todos, saúde direito de cada um: reflexões para a transição da práxis judiciária. In NOBRE, Milton Augusto de Brito; SILVA, Ricardo Augusto Dias da (Coords.). O CNJ e os desafios da efetivação do direito à saúde. Belo Horizonte: Fórum, 2011. p. 82). ${ }^{6}$ Cf. CONSELHO NACIONAL DE JUSTIÇA. Disponível em: <http://www.cnj.jus.br/images/programas/forumdasaude/relatorio_atualizado_da_resolucao107.pdf>. Acesso em: 12 out. 2012.

7 “O pedido de suspensão de liminar ou de segurança é conferido às pessoas jurídicas de direito público por leis extravagantes sempre que houver lesão a um dos interesses públicos relevantes. (...) Objetiva-se, com o pedido de suspensão, sobrestar o cumprimento de liminar ou da ordem concedida, subtraindo seus efeitos, com o que se desobriga a Fazenda Pública do cumprimento da medida". (CUNHA, Leonardo José Carneiro da. A Fazenda Pública em juízo. 8. ed. São Paulo: Dialética, 2010. p. 548).

${ }^{8}$ Cf. SUPREMO TRIBUNAL FEDERAL. Despacho de Convocação de Audiência Pública, de 5 de março de 2009. Disponível em: <http://www.stf.jus.br/arquivo/cms/processoAudienciaPublicaSaude/anexo/Despacho_ Convocatorio.pdf>. Acesso em: 09 out. 2012.

${ }^{9}$ Segundo o Regimento Interno do STF (artigo 21, inciso XVII), o relator do processo pode, se entender necessário, convocar audiência pública para ouvir o depoimento de pessoas com experiência e autoridade em determinado tema, se isto for necessário ao esclarecimento de questões ou circunstâncias de fato, com repercussão geral ou de interesse público. SUPREMO TRIBUNAL FEDERAL. Regimento interno. Disponível em: <http://www.stf.jus.br/arquivo/cms/legislacaoregimentointerno/anexo/ristf_maio_2013_versao_eletronica.pdf>. Acesso em: 11 jun. 2015. 
discutir parâmetros para a prática judiciária no país ${ }^{10}$. Na pauta, o tribunal arrolou a necessidade de debater a responsabilidade dos entes federados em matéria de direito à saúde e, ainda, a obrigação do Estado de (a) fornecer prestação de saúde prescrita por médico não pertencente ao quadro do Sistema Único de Saúde (SUS), (b) custear prestações de saúde não abrangidas pelas políticas públicas existentes, (c) disponibilizar medicamentos e tratamentos experimentais não registrados na Agência Nacional de Vigilância Sanitária (Anvisa) ou não aconselhados nos protocolos clínicos do SUS e (d) fornecer medicamento não licitado e não previsto nas listas do SUS.

A audiência pública durou entre 27 de abril e 7 de maio de 2009 e teve a finalidade especial de promover a participação social por meio de depoimentos de pessoas com experiência e autoridade em relação ao SUS, contribuindo com o deslinde de questões técnicas, científicas, administrativas, políticas e econômicas envolvidas nas decisões judiciais sobre saúde.

Já em 2010, duas iniciativas relevantíssimas do CNJ também buscaram interferir positivamente na prática judiciária relacionada ao direito à saúde. $\mathrm{O}$ órgão editou a Recomendação n. $31 / 2010^{11}$ na qual pede aos tribunais de todo o país que adotem uma série de medidas visando a apoiar magistrados e outros operadores do direito a fim de assegurar maior eficiência na solução das demandas judiciais pertinentes ao direito à saúde.

Dentre as medidas, cumpre destacar a recomendação aos tribunais que lidam com o Direito Sanitário para que celebrem convênios a fim de obter apoio técnico que auxilie os magistrados nas ações que apresentem discussão sobre o quadro clínico de pacientes. Além disso, o CNJ recomendou o seguimento das diretrizes apontadas na audiência pública do STF, realizada entre abril e maio de 2009.

Outra providência do CNJ foi a criação do Fórum Nacional do Judiciário para "monitoramento e resolução das demandas de assistência à saúde", por meio da Resolução n. $107^{12}$. Um dos principais objetivos do Fórum, além do monitoramento das ações judiciais, é a proposição de rotinas processuais voltadas à organização de unidades judiciárias especializadas e, ainda, a proposição de medidas normativas para a prevenção de conflitos judiciários e a definição de estratégias relacionadas ao Direito Sanitário.

\footnotetext{
10 “As audiências públicas são um bom exemplo do firme propósito da Suprema Corte de que a revisão judicial deve ser feita de forma totalmente compatível com outras instituições democráticas. Se uma das principais fontes de legitimidade democrática da Corte vem da força de seus argumentos, é evidente que esta deve estar disposta a ouvir todos os setores da sociedade, especialmente em casos relativos à efetivação de direitos socioeconômicos". (MENDES, Gilmar Ferreira; BRANCO, Paulo Gustavo Gonet. Curso de direito constitucional. 6. ed. São Paulo: Saraiva, 2011. p. 712).

${ }^{11}$ CONSELHO NACIONAL DE JUSTIÇA. Recomendação n. 31, de 30 de março de 2010. Recomenda aos Tribunais a adoção de medidas visando a melhor subsidiar os magistrados e demais operadores do direito, para assegurar maior eficiência na solução das demandas judiciais envolvendo a assistência à saúde. Disponível em: <http://www.cnj.jus.br/atos-normativos?documento=877>. Acesso em: 11 jun. 2015.

${ }^{12}$ CONSELHO NACIONAL DE JUSTIÇA. Resolução n. 107, de 6 de abril de 2010. Disponível em: <http://www.cnj.jus.br/atos-normativos?documento=173>. Acesso em: 11 jun. 2015.
} 
Por sua vez, dados do Ministério da Saúde apontam que o excessivo número de ações judiciais que discutem o acesso às prestações do SUS tem tido efeitos muito relevantes no orçamento do órgão ${ }^{13}$. Em 2005, o montante de recursos despendidos pelo Ministério da Saúde com condenações judiciais foi de aproximadamente R \$ 2,5 milhões; em 2006, R \$ 7,6 milhões; em 2007, R \$ 10,7 milhões; em 2008, R \$ 47,6 milhões; em 2009, R \$ 83,1 milhões; em 2010, R \$ 174,1 milhões; em 2011, R \$ 244

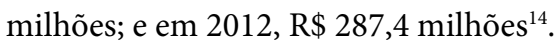

No Estado de Santa Catarina, por exemplo, dados enviados ao Ministério da Saúde indicam que os valores gastos com o cumprimento de decisões judiciais subiram de aproximadamente $R \$ 2,8$ milhões, em 2003, para $R$ \$ 93,4 milhões, em $2010^{15}$.

Ainda segundo o Ministério da Saúde, a excessiva judicialização tem criado alguns entraves ao funcionamento do SUS, a saber: (a) decisões judiciais que determinam o fornecimento de medicamento por prazo muito longo, sem controle de prescrição médica; (b) as ações judiciais asseguram atendimento apenas aos autores e, mesmo que o Ministério da Saúde pretendesse universalizar tais prestações, isso seria impossível com o orçamento disponível; e (c) decisões judiciais que não levam em conta aspectos técnicos ligados ao conceito de integralidade, nem as políticas públicas já formuladas ${ }^{16}$.

Além disso, muitas ações judiciais que demandam determinados tipos de medicamentos são patrocinadas por grupos fraudadores da saúde pública. O litigioso mercado de medicamentos e a concorrência entre laboratórios são de notório conhecimento, de maneira que não é difícil de imaginar que fazer com que o Estado pague pela preferência de determinado remédio resulte de um arranjo prévio entre profissionais de diversas áreas ${ }^{17}$.

Conforme já ressaltado, todos esses dados de ordem técnica, política e econômica têm sido considerados pelos tribunais superiores, conforme se verá na análise de decisões paradigmáticas adiante.

\section{Método}

O presente trabalho enfoca o tratamento dado pela jurisprudência das cortes superiores às ações judiciais que pleiteiam a condenação do Estado para o fornecimento de medicamentos e outras prestações materiais em saúde. Para tanto, foram

\footnotetext{
${ }^{13}$ Além do gasto público próprio e inerente às despesas com saúde, é pertinente trazer as ponderações de Ramon Fagundes Botelho, segundo o qual "o benefício a um único cidadão prejudica o restante da coletividade de cidadão, que veem as verbas destinadas à saúde diminuírem sensivelmente, em detrimento de suas necessidades". (BOTELHO, Ramon Fagundes. A judicialização do direito à saúde. Curitiba: Juruá, 2011. p. 153).

${ }^{14}$ Cf. PORTAL da Saúde. Disponível em: <http://portalsaude.saude.gov.br/portalsaude/arquivos/pdf/2012/ Dez/17/EVOLUcaOGASTOS.pdf>. Acesso em: 27 mar. 2013.

${ }^{15} \mathrm{Cf}$. Id. Ibid.

${ }^{16} \mathrm{Cf}$. Id. Ibid.

${ }^{17}$ DAVIES, Ana Carolina Izidório. Saúde pública e seus limites constitucionais. São Paulo: Verbatim, 2012. p. 97.
} 
adotadas técnicas de pesquisa jurisprudencial e também pesquisa bibliográfica e documental sobre o tema.

Inicialmente, buscaram-se fontes documentais de órgãos públicos que lidam com a judicialização da saúde e suas repercussões, para se destacar a atualidade do tema. Dados do CNJ, da Advocacia-Geral da União e da audiência pública do STF realizada em 2009 demonstraram os impactos do excesso de ações judiciais respectivamente na organização administrativa judiciária e no orçamento público. As conclusões desses órgãos públicos foram cotejadas com as posições doutrinárias.

O estudo, então, evolui à etapa de escolha da jurisprudência a ser avaliada, quando se passou à pesquisa exploratória. Observou-se grande oscilação do entendimento dos tribunais estaduais e tribunais regionais federais, o que, em certa medida, também se verificou nos tribunais superiores. Por conta do caráter uniformizador da jurisprudência do STJ e do STF, optou-se por um enfoque específico no entendimento destas cortes nacionais.

A coleta dos dados jurisprudenciais foi realizada nas páginas eletrônicas dos tribunais superiores. Em um primeiro momento, foram separados todos os casos envolvendo especificamente pedidos de condenação do poder público para o fornecimento de medicamentos e prestações materiais, a contar da instalação do STJ, em 1989. O lapso temporal em questão pretendeu abranger o período pós-Constituição Federal de 1988.

Depois, os julgados emblemáticos, que não se limitaram somente a reproduzir o entendimento prévio sobre $\mathrm{o}$ assunto, foram selecionados para compor os dados do estudo, principalmente por representarem os pontos de inflexão das fases da jurisprudência. Essas viragens jurisprudenciais levaram à divisão do entendimento das cortes superiores em três fases, podendo-se observar claramente a evolução do pensamento dos colegiados rumo a um equilíbrio entre as infinitas demandas em saúde pública e os escassos recursos estatais disponíveis, delineados em políticas públicas.

Enfim, após a consolidação dos dados da pesquisa jurisprudencial, buscou-se uma discussão crítica com apoio na bibliografia selecionada, pretendendo-se contribuir para que a prática judiciária reconheça parâmetros jurídicos consistentes a fim de solucionar juridicamente os dramáticos casos concretos relacionados às ações judiciais em matéria de saúde.

\section{A evolução da jurisprudência dos tribunais superiores}

Há uma natural complexidade que envolve as ações judiciais que discutem o direito à saúde, ante a infinidade de pretensões que podem ser manejadas em juízo, envolvendo uma combinação quase interminável de doenças - muitas delas de raro contato até mesmo para os profissionais de saúde - e as correlatas prestações - medicamentos, próteses, terapias alternativas, vagas em unidade de terapia intensiva etc. 
A par dessa dificuldade, frise-se a parca regulamentação legal sobre os parâmetros da integralidade de assistência, prometida pelo artigo 198, inciso II, da Constituição Federal de 1988. Saliente-se que esse conjunto de fatores levou à edição da Lei n. 12.401/2011 ${ }^{18}$, com escopo de disciplinar o princípio da integralidade de assistência à saúde.

Por essa razão, e tendo em conta a cláusula constitucional de inafastabilidade da jurisdição, coube ao Poder Judiciário criar as balizas para a solução dos difíceis casos concretos envolvidos nas demandas que discutem o direito à saúde. O caráter uniformizador da jurisprudência dos tribunais superiores criou, na consciência judiciária brasileira, uma espécie de normativa a ser seguida para as ações que tratam do tema ${ }^{19}$.

Dessa forma, o estudo da jurisprudência do STF e do STJ é um caminho metodológico indispensável para se compreenderem os parâmetros utilizados pelas cortes nas resoluções das complexas questões do tema ${ }^{20}$.

De fato, é indispensável a análise da evolução jurisprudencial dos dois principais tribunais do país no que se refere ao direito à saúde. Desde logo, porém, é possível apontar ao menos três fases distintas do desenvolvimento da prática judiciária do STF e do STJ.

Na primeira fase, iniciada em meados da década de 1990, denota-se a prevalência das teses da Fazenda Pública, no sentido da impossibilidade de atendimento estatal das demandas judicializadas relacionadas ao direito à saúde.

Na segunda fase, que pode ser verificada a partir de uma série de julgados do ano de 2000, as duas cortes superiores passam a ressaltar aprioristicamente a necessidade de se resguardar o princípio da dignidade da pessoa humana, com base no mínimo existencial, para conceder pleitos ligados às prestações materiais de saúde em detrimento das teses fazendárias. Nessa etapa, nota-se que os ministros se debruçam basicamente no conflito entre mínimo existencial e reserva do possível, sem maiores considerações sobre as especificidades do pedido.

\footnotetext{
${ }^{18}$ BRASIL. Lei n. 12.401 de 28 de abril de 2011. Altera a Lei $n^{\circ}$-8.080, de 19 de setembro de 1990, para dispor sobre a assistência terapêutica e a incorporação de tecnologia em saúde no âmbito do Sistema Único de Saúde - SUS. Disponível em: <http://www.planalto.gov.br/ccivil_03/_Ato2011-2014/2011/Lei/ L12401.htm>. Acesso em: 10 jun. 2015.

19 “O que é a jurisprudência? Significa mais do que um precedente. Pode até ser formada com um precedente. Se o Supremo Tribunal Federal, em sessão plenária, ou o Superior Tribunal de Justiça, em sessão da Corte Especial, decidem num julgamento, em um processo sobre determinada tese, ali estará a jurisprudência. É claro que o prestígio dessa jurisprudência será maior com a ratificação de outros julgados. Não sendo julgamento de órgão plenário, somente pode entender-se a jurisprudência com a consolidação de julgados reiterados". (ROSAS, Roberto. Direito sumular (comentários às súmulas do Supremo Tribunal Federal e do Superior Tribunal de Justiça). 13. ed. São Paulo: Malheiros Ed., 2006. p. 10).

20 “Deve-se observar que o direito, seja na lei, seja na jurisprudência ou em outras fontes, haverá de dar acústica às mutações que se operam no cotidiano das relações sociais, vale dizer, às mudanças contínuas da sociedade, para que possa, assim, refleti-la verdadeiramente, se constitua caixa de ressonância do corpo social que organiza". (LEITE, Rodrigo; JOSINO, Miguel. Análise das divergências jurisprudenciais no STF e STJ. Salvador: JusPodivm, 2011. p. 21).
} 
Finalmente, uma terceira fase inicia-se em meados da década de 2000, quando os tribunais eventualmente começam a negar pedidos ligados ao direito fundamental à saúde, analisando as questões próprias das ações - medicamentos fora da lista nacional, medicamentos experimentais etc. Pode-se dizer que esta terceira fase gerou ao menos três eventos importantes para a judicialização da saúde no Brasil: (a) a realização da audiência pública no STF, em 2009; (b) o julgamento do Agravo Regimental na Suspensão de Tutela Antecipada n. 175, em 17 de março de 2010; e (c) a edição da Lei n. 12.401/2011.

\section{Primeira fase}

O contato inicial dos tribunais com a judicialização do direito à saúde deu-se no início da década de 1990, nos primeiros anos após a promulgação da Constituição Federal de 1988. O novo modelo de assistência à saúde, desenhado pelo constituinte, permitiu a invocação da universalidade e integralidade como argumentos hábeis a possibilitar o pleito de prestações materiais negadas - ou omitidas - na via administrativa.

Nessa primeira etapa, a jurisprudência majoritariamente se orientou pela impossibilidade de interferência do Poder Judiciário nas políticas públicas de saúde. Como exemplo ilustrativo dessa fase, aponta-se o Recurso em Mandado de Segurança n. 6564/RS, julgado pelo STJ, em 23 de maio de 1996.

\subsection{STJ - RMS 6564/RS}

O primeiro precedente do STJ que analisou diretamente um pleito de fornecimento de medicamentos pelo SUS foi o Recurso em Mandado de Segurança n. 6564/RS ${ }^{21}$, apreciado em 1996 pela corte.

\footnotetext{
21 “CONSTITUCIONAL. ADMINISTRATIVO. MANDADO DE SEGURANÇA. DIREITO LIQUIDO E CERTO. INEXISTENCIA. DIREITO LIQUIDO E CERTO, PARA EFEITO DE CONCESSÃO DE SEGURANÇA, E AQUELE RECONHECÍVEL DE PLANO E DECORRENTE DE LEI EXPRESSA OU DE PRECEITO CONSTITUCIONAL, QUE ATRIBUA, AO IMPETRANTE, UM DIREITO SUBJETIVO PRÓPRIO. NORMAS CONSTITUCIONAIS MERAMENTE PROGRAMÁTICAS - AD EXEMPLUM, O DIREITO A SAUDE - PROTEGEM UM INTERESSE GERAL, TODAVIA, NÃO CONFEREM, AOS BENEFICIÁRIOS DESSE INTERESSE, O PODER DE EXIGIR SUA SATISFAÇÃO - PELA VIA DO MANDAMUS - EIS QUE NÃO DELIMITADO O SEU OBJETO, NEM FIXADA A SUA EXTENSÃO, ANTES QUE O LEGISLADOR EXERÇA O MUNUS DE COMPLETÁ-LAS ATRAVES DA LEGISLAÇÃO INTEGRATIVA. ESSAS NORMAS (ARTS. 195, 196, 204 E 227 DA CF) SÃO DE EFICÁCIA LIMITADA, OU, EM OUTRAS PALAVRAS, NÃO TÊM FORÇA SUFICIENTE PARA DESENVOLVER-SE INTEGRALMENTE, 'OU NÃO DISPÕEM DE EFICÁCIA PLENA', POSTO QUE DEPENDEM, PARA TER INCIDÊNCIA SOBRE OS INTERESSES TUTELADOS, DE LEGISLAÇÃO COMPLEMENTAR. NA REGRA JURÍDICO-CONSTITUCIONAL QUE DISPÕE “TODOS TÊM DIREITO E O ESTADO O DEVER" - DEVER DE SAÚDE - COMO AFIANÇAM OS CONSTITUCIONALISTAS, “NA REALIDADE TODOS NÃO TÊM DIREITO, PORQUE A RELAÇÃO JURÍDICA ENTRE O CIDADÃO E O ESTADO DEVEDOR NÃO SE FUNDAMENTA EM VINCULUM JURIS GERADOR DE OBRIGAÇÕES, PELO QUE FALTA AO CIDADÃO O DIREITO SUBJETIVO PÚBLICO, OPONÍVEL AO ESTADO, DE EXIGIR EM JUÍZO, AS PRESTAÇÕES PROMETIDAS A QUE O ESTADO SE OBRIGA POR PROPOSIÇÃO INEFICAZ DOS CONSTITUINTES". NO SISTEMA JURIIDICO PATRIO, A NENHUM ORGÃO OU AUTORIDADE É PERMITIDO REALIZAR DESPESAS SEM A DEVIDA PREVISÃO ORÇAMENTÁRIA, SOB PENA DE INCORRER NO DESVIO DE VERBAS. RECURSO A QUE SE NEGA PROVIMENTO. DECISÃO INDISCREPANTE." (STJ, RMS 6564/ RS, Primeira Turma, Rel. Min. DEMÓCRITO REINALDO, j. 23/05/1996, DJ 17/06/1996, p. 21448).
} 
Tratava-se de um mandado de segurança ajuizado por uma menor, portadora de uma rara doença - síndrome de hipoventilação alveolar central - e internada desde seu nascimento. A impetrante aduzia a necessidade de obter um aparelho de marca-passo (uma espécie de respirador artificial que pudesse lhe garantir a vida), importado dos Estados Unidos a um custo de 50 mil dólares. Por esta razão, noticiava a realização de uma campanha publicitária que havia lhe garantido aproximadamente 29 mil dólares. Apontava a existência de vários requerimentos direcionados ao governador do Estado, desde janeiro de 1994, para que fosse complementada a diferença faltante para aquisição do aparelho, todos indeferidos sob o argumento de ausência de previsão legal. O Tribunal de Justiça do Estado do Rio Grande do Sul, da mesma forma, havia denegado a segurança.

O ministro Demócrito Reinaldo, relator do feito, argumentou que as normas garantidoras do direito à saúde na Constituição Federal teriam natureza programática, carecendo, para sua eficácia, de regulamentação pelo legislador ordinário $^{22}$. Por isso, segundo o relator, não haveria direito líquido e certo a tutelar. Eis suas palavras:

In casu, consoante se observa da inicial e demais peças do processo, a impetrante invoca, a favor de sua pretensão, regras constitucionais (art. $6^{\circ}, 195,196,204$ e 227) que, na lição dos constitucionalistas, constituem "normas programáticas", ou, em outras palavras, "normas de eficácia limitada". Essas normas, embora tenham imediata aplicação, "não têm força para desenvolver-se integralmente" - ou não têm eficácia plena, posto que dependem, para ter incidência sobre os interesses tutelados, de normatividade ulterior - ou de legislação complementar ${ }^{23}$.

Além disso, o magistrado levantou a impossibilidade de realização de despesa sem a autorização orçamentária competente:

A satisfação do direito pleiteado, inclusive com base no preceito da Lei 8.069/90 (Estatuto da Criança e do Adolescente), demandaria previsão expressa de dotações orçamentárias - e com fim específico - ao menos, como acentuou a autoridade coatora, ao nível dos programas aprovados e desenvolvidos pelos serviços de saúde pública, os quais, por seu turno, em sua execução, sujeitam-se ao rigoroso sistema de controle orçamentário ${ }^{24}$.

\footnotetext{
22“Normas programáticas são normas de eficácia limitada que veiculam políticas públicas ou programas de governo, como o resultado de um compromisso assumido pelas Constituições dos Estados contemporâneos. A aplicabilidade plena dessas normas depende de normatividade futura, com base na qual o legislador infraconstitucional, integrando-lhes a eficácia, dê-Ihes capacidade de execução daqueles interesses visados". (CUNHA JÚNIOR, Dirley. Curso de direito constitucional. 2. ed. Salvador: Juspodivm, 2008. p. 164).

${ }^{23}$ STJ, RMS 6564/RS, Primeira Turma, Rel. Min. DEMÓCRITO REINALDO, j. 23/05/1996, DJ 17/06/1996, p. 21448.

${ }^{24}$ Id. Ibid.
} 
Como se denota, o julgado cuidava de um dramático caso envolvendo a imprescindibilidade da prestação material pleiteada para a adequada tutela do direito à vida. Ainda assim, a corte superior acatou o argumento com pelo menos duas cláusulas restritivas dos direitos fundamentais sociais: a natureza programática das normas definidoras de direitos sociais e a reserva do possível, esta como uma condição de restrição fática caracterizada pela escassez de recursos públicos ponderada em situações concretas que envolvam direitos sociais prestacionais ${ }^{25}$.

\section{Segunda fase}

Em um segundo momento, iniciado em 2000, a jurisprudência predominante passa a se filiar a um novo entendimento. Identificada a fundamentalidade material do direito à saúde, como emanação direta do princípio da dignidade da pessoa humana, os tribunais superaram as várias teses defensivas da Fazenda Pública para fazer valer, indiscriminadamente, os pedidos dos usuários do Sistema Único de Saúde.

Exemplos elucidativos dessa posição jurisprudencial são os seguintes julgados, a seguir minudenciados: o Recurso Extraordinário n. 195192/RS e o Agravo Regimental no Recurso Extraordinário n. 271286/RS, ambos do STF, e o Recurso em Mandado de Segurança n. 11183/RS, do STJ.

\subsection{STF - RE 195192/RS}

Uma questão até então nova foi enfrentada pelo Supremo Tribunal Federal no julgamento do Recurso Extraordinário n. 195.192/RS ${ }^{26}$, em 2000, originariamente um mandado de segurança na instância a quo. Tratava-se de um pedido de menor, portador de rara doença metabólica denominada fenilcetonuria, para que lhe fosse custeado, pelo Estado do Rio Grande do Sul, medicamento importado dos Estados Unidos. O Tribunal de Justiça do Estado do Rio Grande do Sul havia concedido a segurança.

O principal argumento deduzido pela Fazenda Pública Estadual foi a inaplicabilidade do artigo 196 da Constituição Federal de 1988, que teria natureza programática.

\footnotetext{
${ }^{25}$ MOREIRA, Alinie da Matta. As restrições em torno da reserva do possível: uma análise crítica. Belo Horizonte: Fórum, 2011. p. 99.

26“MANDADO DE SEGURANÇA - ADEQUAÇÃO - INCISO LXIX, DO ARTIGO 5, DA CONSTITUIÇÃO FEDERAL. Uma vez assentado no acórdão proferido o concurso da primeira condição da ação mandamental - direito líquido e certo - descabe concluir pela transgressão ao inciso LXIX do artigo $5^{\circ}$ da Constituição Federal. SAÚDE - AQUISIÇÃO E FORNECIMENTO DE MEDICAMENTOS - DOENÇA RARA. Incumbe ao Estado (gênero) proporcionar meios visando a alcançar a saúde, especialmente quando envolvida criança e adolescente. O Sistema Único de Saúde torna a responsabilidade linear alcançando a União, os Estados, o Distrito Federal e os Municípios." (STF, RE 195192/RS, Segunda Turma, Rel. Min. Marco Aurélio, j. 22/02/2000; DJ 31/03/2000, p. 60).
} 
O recurso não chegou a ser conhecido, mas o ministro Marco Aurélio, relator do feito, teceu considerações importantes sobre a questão de fundo:

No caso, restou constatada enfermidade rara e que alcança cerca de vinte crianças em todo o Estado do Rio Grande do Sul com sérios riscos para a saúde e desenvolvimento das mesmas. $\mathrm{O}$ Estado deve assumir as funções que lhe são próprias, sendo certo, ainda, que problemas orçamentários não podem obstaculizar o implemento do que previsto constitucionalmente ${ }^{27}$.

Como se percebe, neste caso o STF não fala propriamente em mínimo existencial ou reserva do possível, mas sinaliza com o entendimento de que "problemas orçamentários não podem obstaculizar o implemento do que previsto constitucionalmente".

\subsection{STJ - RMS 11183/PR}

A jurisprudência do STJ começou a mudar em 2000, com o julgamento do Recurso em Mandado de Segurança n. 11183/PR ${ }^{28}$ e já influenciado pela posição do STF exarada no Recurso Extraordinário n. 195.192. Tratava-se de um mandado de segurança impetrado junto ao Tribunal de Justiça do Estado do Paraná, no qual a impetrante pretendida o fornecimento de medicamento para tratamento de grave doença neurológica - esclerose lateral amiotrófica.

\footnotetext{
${ }^{27}$ STF, RE 195192/RS, Segunda Turma, Rel. Min. Marco Aurélio, j. 22/02/2000; DJ 31/03/2000, p. 60

28 "CONSTITUCIONAL. RECURSO ORDINÁRIO. MANDADO DE SEGURANÇA OBJETIVANDO O FORNECIMENTO DE MEDICAMENTO (RILUZOL/RILUTEK) POR ENTE PÚBLICO À PESSOA PORTADORA DE DOENÇA GRAVE: ESCLEROSE LATERAL AMIOTRÓFICA - ELA. PROTEÇÃO DE DIREITOS FUNDAMENTAIS. DIREITO À VIDA (ART. $5^{\circ}$, CAPUT, CF/88) E DIREITO À SAÚDE (ARTS. $6^{\circ} \mathrm{E}$ 196, CF/88). ILEGALIDADE DA AUTORIDADE COATORA NA EXIGÊNCIA DE CUMPRIMENTO DE FORMALIDADE BUROCRÁTICA. 1 - A existência, a validade, a eficácia e a efetividade da Democracia está na prática dos atos administrativos do Estado voltados para o homem. A eventual ausência de cumprimento de uma formalidade burocrática exigida não pode ser óbice suficiente para impedir a concessão da medida porque não retira, de forma alguma, a gravidade e a urgência da situação da recorrente: a busca para garantia do maior de todos os bens, que é a própria vida. 2 - É dever do Estado assegurar a todos os cidadãos, indistintamente, o direito à saúde, que é fundamental e está consagrado na Constituição da República nos artigos $6^{\circ}$ e 196.3 - Diante da negativa/omissão do Estado em prestar atendimento à população carente, que não possui meios para a compra de medicamentos necessários à sua sobrevivência, a jurisprudência vem se fortalecendo no sentido de emitir preceitos pelos quais os necessitados podem alcançar o benefício almejado (STF, AG $n^{\circ}$ 238.328/RS, Rel. Min. Marco Aurélio, DJ 11/05/99; STJ, REsp n² 249.026/PR, Rel. Min. José Delgado, DJ 26/06/2000). 4 - Despicienda de quaisquer comentários a discussão a respeito de ser ou não a regra dos arts. $6^{\circ}$ e 196 , da CF/88, normas programáticas ou de eficácia imediata. Nenhuma regra hermenêutica pode sobrepor-se ao princípio maior estabelecido, em 1988, na Constituição Brasileira, de que 'a saúde é direito de todos e dever do Estado (art. 196). 5 - Tendo em vista as particularidades do caso concreto, faz-se imprescindível interpretar a lei de forma mais humana, teleológica, em que princípios de ordem ético-jurídica conduzam ao único desfecho justo: decidir pela preservação da vida. 6 - Não se pode apegar, de forma rígida, à letra fria da lei, e sim, considerá-la com temperamentos, tendo-se em vista a intenção do legislador, mormente perante preceitos maiores insculpidos na Carta Magna garantidores do direito à saúde, à vida e à dignidade humana, devendo-se ressaltar o atendimento das necessidades básicas dos cidadãos. 7 - Recurso ordinário provido para o fim de compelir o ente público (Estado do Paraná) a fornecer o medicamento Riluzol (Rilutek) indicado para o tratamento da enfermidade da recorrente." (STJ, RMS 11183/PR, Primeira Turma, Rel. Min. José Delgado, j. 22/08/2000; DJ 04/09/2000, p. 121).
} 
A corte estadual denegou a segurança, sob o argumento de não ser abusiva a exigência do Estado do Paraná para que a impetrante comparecesse a exames clínicos atualizados para averiguar sua situação de saúde e eventual enquadramento nas rotinas do SUS.

A impetrante aviou o recurso ao STJ, aduzindo, dentre outros fundamentos, a existência de atestados de três médicos diferentes - ainda que não integrantes do SUS indicando a necessidade do medicamento e, também, a preponderância do direito à vida.

Nesse precedente, o STJ deu especial atenção ao gravíssimo estado de saúde da recorrente. Em seu voto, o ministro relator destacou algumas informações técnicas fornecidas pela Associação Brasileira de Esclerose Lateral Amiotrófica e pelo Congresso Internacional sobre Esclerose Lateral Amiotrófica, realizado em 1999 no Canadá, para concluir que o medicamento pleiteado teria eficácia, ainda que parcial, no tratamento da doença.

Em outra senda, o relator advertiu que questões de ordem financeira ou política - ou de "custosa credibilidade", segundo suas palavras - não podem se sobrepor ao direito da paciente à vida. Observe-se o raciocínio do ministro, apontando a prevalência do mínimo existencial sobre a reserva do possível, mesmo que sem se referir a esta exata terminologia:

Penso que os argumentos articulados pelo Estado do Paraná, além de serem juridicamente inconsistentes, revelam o total desprezo por parte das autoridades públicas encarregadas da saúde no país. O Estado/recorrido preocupa-se, nitidamente, em contrapor-se à situação delineada nos autos com teses jurídicas de custosa credibilidade (desestabilização do Estado de Direito; quebra orçamentária; anarquia dos poderes; falência institucional) para negar à ora recorrente o sagrado direito à sobrevivência ${ }^{29}$.

O substancioso voto do relator apresentou, em síntese, as seguintes conclusões: a vida é o bem mais precioso do ser humano, sem o que os demais valores sociais não têm qualquer significado; o eventual descumprimento de formalidades burocráticas não pode se sobrepor à urgentíssima situação da saúde da recorrente; não há sentido em discutir se as normas constitucionais do direito à saúde têm natureza meramente programática, tendo em vista a relevância do seu conteúdo; a doença da recorrente é gravíssima. Com base nesses termos, a segurança foi concedida.

\subsection{STF - AgRg no RE 271.286/RS}

Um dos precedentes mais importantes do STF na judicialização da saúde, e que serviu reiteradamente de fundamento para outras decisões judiciais, foi o

\footnotetext{
${ }^{29}$ STJ, RMS 11183/PR, Primeira Turma, Rel. Min. José Delgado, j. 22/08/2000; DJ 04/09/2000, p. 121
} 
Agravo Regimental no Recurso Extraordinário n. 271286/RS ${ }^{30}$. Pela primeira vez na corte, o assunto foi tratado com profundidade e a ratio da decisão demonstra a preocupação em tratar a saúde como prerrogativa indisponível.

Na oportunidade, discutiu-se a obrigação solidária do Estado do Rio Grande do Sul e do Município de Porto Alegre no fornecimento gratuito de medicamentos para pacientes portadores da Síndrome da Imunodeficiência Adquirida (AIDS). O Tribunal de Justiça do Estado do Rio Grande do Sul havia decidido que tal obrigação era, de fato, solidária entre os entes federados e, portanto, cabia o fornecimento gratuito de medicamentos contra a AIDS para pacientes destituídos de recursos financeiros, mormente em razão da Lei n. 9.313/1996 ${ }^{31}$.

No recurso, o Município de Porto Alegre sustentou a violação do artigo 167, inciso I, da Constituição Federal de $1988^{32}$, que veda o início de programas e projetos não incluídos na lei orçamentária anual, argumentando ainda que caberia ao Poder Executivo o poder de iniciativa da lei de orçamento da seguridade social. Além disso, levantou a ideia de que a Lei n. 9.313/1996 dependeria, para sua eficácia, de

30 “PACIENTE COM HIV/AIDS - PESSOA DESTITUÍDA DE RECURSOS FINANCEIROS - DIREITO À VIDA E À SAÚDE - FORNECIMENTO GRATUITO DE MEDICAMENTOS - DEVER CONSTITUCIONAL DO PODER PÚBLICO (CF, ARTS. 5 ${ }^{\circ}$ CAPUT, E 196) - PRECEDENTES (STF) - RECURSO DE AGRAVO IMPROVIDO. O DIREITO À SAÚDE REPRESENTA CONSEQÜÊNCIA CONSTITUCIONAL INDISSOCIÁVEL DO DIREITO À VIDA. - O direito público subjetivo à saúde representa prerrogativa jurídica indisponível assegurada à generalidade das pessoas pela própria Constituição da República (art. 196). Traduz bem jurídico constitucionalmente tutelado, por cuja integridade deve velar, de maneira responsável, o Poder Público, a quem incumbe formular - e implementar - políticas sociais e econômicas idôneas que visem a garantir, aos cidadãos, inclusive àqueles portadores do vírus HIV, o acesso universal e igualitário à assistência farmacêutica e médico-hospitalar. - 0 direito à saúde - além de qualificar-se como direito fundamental que assiste a todas as pessoas - representa consequência constitucional indissociável do direito à vida. O Poder Público, qualquer que seja a esfera institucional de sua atuação no plano da organização federativa brasileira, não pode mostrar-se indiferente ao problema da saúde da população, sob pena de incidir, ainda que por censurável omissão, em grave comportamento inconstitucional. A INTERPRETAÇÃO DA NORMA PROGRAMÁTICA NÃO PODE TRANSFORMÁ- LA EM PROMESSA CONSTITUCIONAL INCONSEQUENTE. - O caráter programático da regra inscrita no art. 196 da Carta Política - que tem por destinatários todos os entes políticos que compõem, no plano institucional, a organização federativa do Estado brasileiro - não pode converter-se em promessa constitucional inconsequente, sob pena de o Poder Público, fraudando justas expectativas nele depositadas pela coletividade, substituir, de maneira ilegítima, o cumprimento de seu impostergável dever, por um gesto irresponsável de infidelidade governamental ao que determina a própria Lei Fundamental do Estado. DISTRIBUIÇÃO GRATUITA DE MEDICAMENTOS A PESSOAS CARENTES. - O reconhecimento judicial da validade jurídica de programas de distribuição gratuita de medicamentos a pessoas carentes, inclusive àquelas portadoras do vírus HIV/AIDS, dá efetividade a preceitos fundamentais da Constituição da República (arts. $5^{\circ}$, caput, e 196) e representa, na concreção do seu alcance, um gesto reverente e solidário de apreço à vida e à saúde das pessoas, especialmente daquelas que nada têm e nada possuem, a não ser a consciência de sua própria humanidade e de sua essencial dignidade. Precedentes do STF." (STF, AgRg no RE 271.286/RS, Segunda Turma. Min. Celso de Mello, j. 12/09/2000, DJ 24/11/2000, p. 101)

${ }^{31}$ BRASIL. Lei n. 9.313 de 13 de novembro de 1996. Dispõe sobre a distribuição gratuita de medicamentos aos portadores de HIV e doentes de AIDS. Disponível em: < http://www.planalto.gov.br/ccivil_03/leis/ 19313.htm>. Acesso em: 10 jun. 2015.

32 “Art. 167. São vedados: I - o início de programas ou projetos não incluídos na lei orçamentária anual”. BRASIL. Constituição da República Federativa do Brasil de 1988. Disponível em: < http://www.planalto.gov.br/ ccivil_03/constituicao/constituicaocompilado.htm>. Acesso em: 10 jun. 2015. 
regulamento previsto em seu artigo $2^{033}$, razão pela qual o acórdão recorrido estaria afrontando o artigo 165 , inciso $\mathrm{III}^{34}$, e parágrafo $5^{\mathrm{035}}$, além do artigo $5^{\circ}$, inciso $\mathrm{II}^{36}$, todos da Constituição Federal de 1988.

$\mathrm{O}$ ministro Celso de Mello, relator, ponderou inicialmente que o direito à saúde, em razão de sua essência de direito fundamental, cria um dever para o Estado de estabelecer e implementar políticas públicas para sua proteção. Eis as suas palavras:

O sentido de fundamentalidade do direito à saúde - que representa, no contexto da evolução histórica dos direitos básicos da pessoa humana, uma das expressões mais relevantes das liberdades reais ou concretas - impõe ao Poder Público um dever de prestação positiva que somente se terá cumprido, pelas instâncias governamentais, quando estas adotarem providências destinadas a promover, em plenitude, a satisfação efetiva da determinação ordenada pelo texto constitucional ${ }^{37}$.

Mais adiante, o ministro Celso de Mello aludiu à impossibilidade de obstar pleitos judiciais que busquem a efetivação do direito à saúde:

Cumpre assinalar, finalmente, que a essencialidade do direito à saúde fez com que o legislador constituinte qualificasse como prestações de relevância pública, as ações e serviços de saúde (CF, art. 197), em ordem a legitimar o Ministério Público e o Poder Judiciário naquelas hipóteses em que órgãos estatais, anomalamente, deixassem de respeitar o mandamento constitucional, frustrando-lhe, arbitrariamente, a eficácia jurídico-social por intolerável omissão, seja por qualquer outra inaceitável modalidade de comportamento governamental desviante ${ }^{38}$.

A análise dos fundamentos da decisão, contidos no voto do relator e adotados por unanimidade pelo colegiado, denota que o STF abraçou, mesmo sem menção

\footnotetext{
33 “Art. $2^{\circ}$ As despesas decorrentes da implementação desta Lei serão financiadas com recursos do orçamento da Seguridade Social da União, dos Estados, do Distrito Federal e dos Municípios, conforme regulamento". BRASIL. Lei n. 9.313/1996, cit.

34 “Art. 165. Leis de iniciativa do Poder Executivo estabelecerão: (...) III - os orçamentos anuais”. BRASIL. Constituição da República Federativa do Brasil de 1988, cit.

35 “ $\S 5^{\circ}$ - A lei orçamentária anual compreenderá: I - o orçamento fiscal referente aos Poderes da União, seus fundos, órgãos e entidades da administração direta e indireta, inclusive fundações instituídas e mantidas pelo Poder Público; II - o orçamento de investimento das empresas em que a União, direta ou indiretamente, detenha a maioria do capital social com direito a voto; III - o orçamento da seguridade social, abrangendo todas as entidades e órgãos a ela vinculados, da administração direta ou indireta, bem como os fundos e fundações instituídos e mantidos pelo Poder Público". BRASIL. Constituição da República Federativa do Brasil de 1988, cit.

36 “Art. $5^{\circ}$ Todos são iguais perante a lei, sem distinção de qualquer natureza, garantindo-se aos brasileiros e aos estrangeiros residentes no País a inviolabilidade do direito à vida, à liberdade, à igualdade, à segurança e à propriedade, nos termos seguintes: (...) II - ninguém será obrigado a fazer ou deixar de fazer alguma coisa senão em virtude de lei;". BRASIL. Constituição da República Federativa do Brasil de 1988, cit.

${ }^{37}$ STF, AgRg no RE 271.286/RS, Segunda Turma. Min. Celso de Mello, j. 12/09/2000, DJ 24/11/2000, p. 101. ${ }^{38}$ Id. Ibid.
} 
expressa, a ideia de que o direito à saúde configura parcela do mínimo existencial e que, por esta razão, deve ser obrigatoriamente concretizado pelo poder público. Comportamento contrário seria tido como "intolerável omissão". Assim, afastou a tese fazendária de inaplicabilidade direta do artigo 196 da Constituição Federal de 1988, bem como a suposta impossibilidade de que o Poder Judiciário pudesse se imiscuir no orçamento público, de iniciativa exclusiva do Poder Executivo.

\section{Terceira fase}

Uma nova etapa da evolução jurisprudencial do direito à saúde começou a se passar em meados da década de 2000. Na ocasião, os tribunais superiores começaram a superar a ideia de que o direito à saúde e sua diretriz da integralidade significariam um "direito a tudo". Passou-se a uma análise mais minudente do caso concreto, com considerações de ordem técnica, inaugurando na jurisprudência uma série de decisões que negou aos usuários do SUS determinadas prestações que estariam em desacordo com balizas das políticas públicas previamente delineadas.

Esse novo momento da jurisprudência brasileira culminou com a audiência pública de 2009, no STF, que levou, finalmente, à estipulação de parâmetros bem mais nítidos para a racionalização da prática judiciária do direito à saúde. São exemplos dessa fase jurisprudencial: o Mandado de Segurança n. 8895/DF, do STJ, a Suspensão de Segurança n. 3073 e o Agravo Regimental na Tutela Antecipada n. 175, os dois últimos do STF.

\subsection{STJ - MS 8895/DF}

No Mandado de Segurança n. 8895/DF ${ }^{39}$, o STJ deparou-se com um caso complexo, que mereceu amplo estudo de aspectos técnicos das ciências médicas. Tratava-se de um pedido para que o SUS custeasse tratamento de uma rara doença oftalmológica, conhecida como retinose pigmentar, em Cuba. Segundo o impetrante, somente naquele país havia tratamento eficaz para a doença.

A autoridade impetrada argumentou, dentre outros pontos, que pareceres técnicos do próprio SUS e do Conselho Brasileiro de Oftalmologia indicavam que o tratamento oferecido em Cuba não surtiria os efeitos propagados pelo autor. Assentou ainda que as regras constitucionais sobre o SUS cingiam-se ao território nacional.

\footnotetext{
39،ADMINISTRATIVO - SERVIÇO DE SAÚDE - TRATAMENTO NO EXTERIOR - RETINOSE PIGMENTAR. 1. Parecer técnico do Conselho Brasileiro de Oftalmologia desaconselha o tratamento da 'retinose pigmentar' no Centro Internacional de Retinoses Pigmentária em Cuba, o que levou o Ministro da Saúde a baixar a Portaria 763, proibindo o financiamento do tratamento no exterior pelo SUS. 2. Legalidade da proibição, pautada em critérios técnicos e científicos. 3. A Medicina social não pode desperdiçar recursos com tratamentos alternativos, sem constatação quanto ao sucesso nos resultados. 4. Mandado de segurança denegado." (STJ, MS 8895/DF, Primeira Seção, Rel. Min. Eliana Calmon, j. 22/10/2003, DJ 07/06/2004, p. 151).
} 
Em seu voto, a relatora, ministra Eliana Calmon, mencionou que várias instâncias técnicas haviam indicado a ineficácia do tratamento pleiteado. Anotou que o Conselho Brasileiro de Oftalmologia considerava não haver comprovação científica do tratamento oferecido em Cuba e, por conta dessa posição, o Ministério da Saúde havia editado a Portaria n. 763/1994, que vedava o custeio de tratamento de retinose pigmentar no exterior. Por isso, denegou a segurança, aduzindo os riscos de desorganização do sistema de saúde com o custeio de tratamentos experimentais:

Entendo que a recusa da autoridade coatora está devidamente respaldada na conclusão do órgão técnico que congrega os especialistas. Dentro do que foi até aqui exposto, independentemente da análise do dever do Estado em patrocinar os tratamentos, alguns deles até no exterior, no específico caso da doença de que é portador o impetrante, não há recomendação médico-científica. No campo do Direito administrativo, sobre o tema tenho a compreensão de que o serviço médico-social, prestado pelo Estado via órgão competente, além da observância do parecer técnico, deve atentar para os critérios próprios do serviço, jungido a um orçamento e a uma política de prioridades, própria do executivo. A Medicina social a cargo do Estado tem, necessariamente, de fixar critérios para os atendimentos excepcionais, dentre os quais os dispendiosos tratamentos no exterior, sob pena de haver um comprometimento de toda a política de saúde ${ }^{40}$.

A posição da relatora, apesar de vencedora no julgamento, não foi acompanhada à unanimidade. Os ministros José Delgado e Luiz Fux restaram vencidos, mas é interessante verificar seus argumentos. O ministro José Delgado, em breves palavras, assentou a necessidade de prevalência do princípio da dignidade da pessoa humana sobre a discussão científica em torno no caso:

Sr. Presidente, eminentes Ministros, o art. $1^{\circ}$, incisos II e III, da Constituição Federal, diz que o objetivo fundamental da República Federativa do Brasil, dentre tantos, é zelar pela dignidade humana e pela cidadania. Não há dignidade humana nem cidadania mais forte a ser zelada pelo Estado do que proporcionar todos os meios que sejam possíveis a quem necessita da saúde, em uma situação como a descrita, para que haja uma tentativa de solução. Não me impressiona a discussão científica a respeito porque não é o que está em jogo. O que me surpreende é que um cidadão está rigorosamente em vias de ficar cego, se já não ficou, sem direito à luz, sem direito ao sol, enfim, ao mínimo direito do cidadão, que é a visão ${ }^{41}$.

\footnotetext{
${ }^{40}$ STJ, MS 8895/DF, Primeira Seção, Rel. Min. Eliana Calmon, j. 22/10/2003, DJ 07/06/2004, p. 151.

${ }^{41}$ Id. Ibid.
} 
O ministro Luiz Fux, por sua vez, também adotou a premissa da absoluta prioridade do princípio da dignidade da pessoa humana:

Sou um perseverante escudeiro da dignidade da pessoa humana, dos valores imanentes à vida e à esperança do ser humano. Creio que é a nossa tarefa diuturna. De sorte que - mais uma vez parabenizo a Sra. Ministra Eliana Calmon e até, de antemão, já havia pedido seu voto, porque há casos e casos -, e na dúvida, devemos opinar exatamente pela esperança de esse cidadão poder se curar em um centro mais avançado, máxime porque, muito embora haja total juridicidade na parte do voto, que esclarece a respeito da socialização da Medicina e da impossibilidade de o País atender a todos, mais uma vez, entre o direito e a justiça, ficarei com a solução que considero mais justa ${ }^{42}$.

Esse precedente do STJ inaugura uma nova perspectiva de abordagem da judicialização da saúde na corte. Diante do aumento da demanda e da crescente complexidade dos temas, os ministros passaram a esmiuçar as questões técnicas relacionadas às ciências médicas, iniciando uma fase em que o princípio da dignidade da pessoa humana deixa de ser um argumento absoluto para a obtenção das prestações materiais em saúde. A solução jurídica dos casos, então, não se restringe tão somente à discussões sobre a eficácia de normas constitucionais, senão também sobre a eficiência de tratamentos médicos, sua previsão no SUS etc.

É interessante ainda dar destaque a um ponto do voto da ministra Eliana Calmon: a necessidade de fixação de critérios para o atendimento de demandas excepcionais, sob pena de risco de desorganização do sistema de saúde.

\subsection{STF - SS 3073/RN}

Os casos concretos trazidos ao STF, pela rápida via prevista na Lei n. $4.348 / 1964^{43}$, passaram a se tornar mais complexos na medida em que os operadores do direito compreenderam a amplitude possível do direito à saúde.

\footnotetext{
${ }^{42}$ STJ, MS 8895/DF, Primeira Seção, Rel. Min. Eliana Calmon, j. 22/10/2003, DJ 07/06/2004.

${ }^{43} \mathrm{~A}$ Lei $\mathrm{n}^{\circ} 4.348$, de 26 de junho de 1964 , em seu artigo $4^{\circ}$, permitia que a liminar ou a decisão em mandado de segurança fosse submetida ao procedimento de suspensão, junto ao tribunal com a respectiva competência recursal, se houvesse fundado risco de lesão à ordem, à saúde, à segurança ou à economia públicas. Este texto legal foi revogado pela Lei n. 12.016/2009 que manteve a previsão normativa em seu artigo 15. Na visão de Leonardo José Carneiro Cunha, o pedido de suspensão não tem natureza recursal, já que recurso é somente aquele que esteja previsto ou taxado em lei como tal. Assim, o pedido de suspensão (de liminar, de tutela antecipada, de segurança) funciona como uma espécie de "cautelar ao contrário", devendo haver demonstração de periculum in mora inverso, caracterizado pela ofensa a um dos citados interesses públicos relevantes, e, ainda, um mínimo de plausibilidade na tese da Fazenda Pública. (CUNHA, Leonardo José Carneiro. A Fazenda Pública em juízo. 8. ed. São Paulo: Dialética, 2010, p. 555). É relevante apontar que o Superior Tribunal de Justiça, por sua vez, considera que o pedido de suspensão ostenta feição política e não está sujeito, portanto, a um estrito juízo de legalidade (STJ, AgRg-Ag 121.304/MG, Segunda Turma, Rel. Min. Ari Pargendler, j. 16/12/1996; DJ 03/03/1997, p. 4636).
} 
No julgamento da Suspensão de Segurança n. 3073/RN ${ }^{44}$ decidida monocraticamente pela Presidência da corte, discutiu-se, dentre outras questões

44 “O Estado do Rio Grande do Norte, com fundamento no art. $4^{\circ}$ da Lei 4.348 , de 26 de junho de 1964 , requer a suspensão da execução da liminar concedida pela desembargadora relatora do Mandado de Segurança $n^{\circ}$ 2006.006795-0 (fls. 31-35), em trâmite no TJ/RN, que determinou àquele ente federado o fornecimento dos medicamentos Mabithera (Rituximabe) + Chop ao impetrante, paciente portador de câncer, nos moldes da prescrição médica. 0 requerente sustenta, em síntese: a) inadequação do mandado de segurança, pois, "em caso de pedido de medicamentos, é necessária perícia que verifique a plausibilidade da indicação médica feita pelo médico particular" (fl. 5); b) ocorrência de grave lesão à ordem e à economia públicas, porquanto a liminar impugnada viola o princípio da legalidade orçamentária (Constituição da República, art. 167), certo que "o Estado não tem previsão orçamentária para suprir a população com todos os medicamentos que esta demande, não podendo arcar com o provisionamento integral de fármacos de que necessite cada cidadão residente no território estadual" (fl. 10). Nesse contexto, ressalta a necessidade de observância da cláusula da reserva do financeiramente possível e o fato de que os medicamentos requeridos não estão inseridos no âmbito do Programa de Dispensação de Medicamentos em Caráter Excepcional, estabelecido, por intermédio do Poder Executivo, conjuntamente pela União, Estados e Municípios; c) impossibilidade de o Poder Judiciário “c) impossibilidade de o Poder Judiciário "desenvolver ou efetivar direitos sem que existam meios materiais disponíveis para tanto" (fl. 12). Além disso, aduz que não se nega a fornecer todo e qualquer medicamento ao impetrante, apenas propõe a indicação de outros similares, uma vez que o medicamento solicitado não se encontra relacionado na lista do Ministério da Saúde; d) caráter experimental do medicamento pleiteado (Rituximabe), o qual se encontra em estudo "em razão de pesquisas haverem concluído que ele proporciona o aparecimento de hepatite nos pacientes que o utilizam" (fl. 15). 2. A Presidência do Tribunal de Justiça do Estado do Rio Grande do Norte determinou a remessa dos autos a esta Corte (fls. 36-38). 3. A Procuradoria-Geral da República opinou pelo indeferimento do pedido (fls. 45-46). 4. Inicialmente, reconheço que a controvérsia instaurada no mandado de segurança em apreço evidencia a existência de matéria constitucional: alegação de ofensa aos arts. $6^{\circ} \mathrm{e}$ 196 da Constituição da República e aos princípios da dignidade da pessoa humana e da solidariedade. Dessa forma, cumpre ter presente que a Presidência do Supremo Tribunal Federal dispõe de competência para examinar questão cujo fundamento jurídico é de natureza constitucional (art. 297 do RISTF, c/c art. 25 da Lei 8.038/90), conforme firme jurisprudência desta Corte, destacando-se os seguintes julgados: Rcl 475/DF, rel. Ministro Octavio Gallotti, Plenário, DJ 22.4.1994; Rcl 497-AgR/RS, rel. Ministro Carlos Velloso, Plenário, DJ 06.4.2001; SS 2.187-AgR/SC, rel. Ministro Maurício Corrêa, DJ 21.10.2003; e SS 2.465/SC, rel. Min. Nelson Jobim, DJ 20.10.2004. 5. A Lei 4.348/64, em seu art. $4^{\circ}$, autoriza o deferimento do pedido de suspensão de segurança para evitar grave lesão à ordem, à saúde, à segurança e à economia públicas. Verifico estar devidamente configurada a lesão à ordem pública, considerada em termos de ordem administrativa, porquanto a execução de decisões como a ora impugnada afeta o já abalado sistema público de saúde. Com efeito, a gestão da política nacional de saúde, que é feita de forma regionalizada, busca uma maior racionalização entre o custo e o benefício dos tratamentos que devem ser fornecidos gratuitamente, a fim de atingir o maior número possível de beneficiários. Entendo que a norma do art. 196 da Constituição da República, que assegura o direito à saúde, refere-se, em princípio, à efetivação de políticas públicas que alcancem a população como um todo, assegurando-lhe acesso universal e igualitário, e não a situações individualizadas. A responsabilidade do Estado em fornecer os recursos necessários à reabilitação da saúde de seus cidadãos não pode vir a inviabilizar o sistema público de saúde. No presente caso, ao se deferir o custeio do medicamento em questão em prol do impetrante, está-se diminuindo a possibilidade de serem oferecidos serviços de saúde básicos ao restante da coletividade. Ademais, o medicamento solicitado pelo impetrante, além de ser de custo elevado, não consta da lista do Programa de Dispensação de Medicamentos em Caráter Excepcional do Ministério da Saúde, certo, ainda, que o mesmo se encontra em fase de estudos e pesquisas. Constato, também, que o Estado do Rio Grande do Norte não está se recusando a fornecer tratamento ao impetrante. É que, conforme asseverou em suas razões, "o medicamento requerido é um plus ao tratamento que a parte impetrante já está recebendo" (fl. 14). Finalmente, no presente caso, poderá haver o denominado "efeito multiplicador" (SS 1.836-AgR/RJ, rel. Min. Carlos Velloso, Plenário, unânime, DJ 11.10.2001), diante da existência de milhares de pessoas em situação potencialmente idêntica àquela do impetrante. 6. Ante o exposto, defiro o pedido para suspender a execução da liminar concedida nos autos do Mandado de Segurança $n^{\circ}$ 2006.006795-0 (fls. 31-35), em trâmite no Tribunal de Justiça do Estado do Rio Grande do Norte. Comunique-se, com urgência. Publique-se". (STF, SS 1073, Rel. Min. Presidente, proferida pela Min. Presidente Ellen Gracie, j. 09/02/2007, DJ 14/02/2007, p. 21). 
habitualmente presentes nesse tipo de demanda, a possibilidade de obrigar o poder público ao fornecimento de medicamento experimental. No caso concreto, tratava-se de um mandado de segurança impetrado no Tribunal de Justiça do Estado do Rio Grande do Norte, em que liminarmente foi ordenado à Fazenda Pública Estadual que fornecesse ao impetrante o medicamento Mabithera (rituximabe).

A presidente do STF na época ministra Ellen Gracie, entendeu configurada a lesão à ordem pública, seja pelo custo do medicamento, seja por não estar previsto na lista oficial de fármacos do SUS. Observe-se:

Entendo que a norma do art. 196 da Constituição da República, que assegura o direito à saúde, refere-se, em princípio, à efetivação de políticas públicas que alcancem a população como um todo, assegurando-lhe acesso universal e igualitário, e não a situações individualizadas. A responsabilidade do Estado em fornecer os recursos necessários à reabilitação da saúde de seus cidadãos não pode vir a inviabilizar o sistema público de saúde. No presente caso, ao se deferir o custeio do medicamento em questão em prol do impetrante, está-se diminuindo a possibilidade de serem oferecidos serviços de saúde básicos ao restante da coletividade. Ademais, o medicamento solicitado pelo impetrante, além de ser de custo elevado, não consta da lista do Programa de Dispensação de Medicamentos em Caráter Excepcional do Ministério da Saúde, certo, ainda, que o mesmo se encontra em fase de estudos e pesquisas ${ }^{45}$.

A decisão traz um importante parâmetro para a judicialização da saúde: medicamentos experimentais, por razões óbvias, não constam na lista oficial do SUS e, portanto, não podem ser dispensados por ordem judicial.

\subsection{STF - 0 STA 175-AgR/CE}

As experiências trazidas pela audiência pública sobre direito à saúde e a própria prática anterior da corte levaram o STF, em um julgado emblemático, à fixação de parâmetros bem mais definidos para o tema. Trata-se do julgamento do Agravo Regimental na Suspensão de Tutela Antecipada n. 175/CE ${ }^{46}$.

\footnotetext{
${ }^{45}$ STF, SS 1073, Rel. Min. Presidente, proferida pela Min. Presidente Ellen Gracie, j. 09/02/2007, DJ 14/02/2007, p. 21.

46 “Suspensão de Segurança. Agravo Regimental. Saúde pública. Direitos fundamentais sociais. Art. 196 da Constituição. Audiência Pública. Sistema Único de Saúde - SUS. Políticas públicas. Judicialização do direito à saúde. Separação de poderes. Parâmetros para solução judicial dos casos concretos que envolvem direito à saúde. Responsabilidade solidária dos entes da Federação em matéria de saúde. Fornecimento de medicamento: Zavesca (miglustat). Fármaco registrado na ANVISA. Não comprovação de grave lesão à ordem, à economia, à saúde e à segurança públicas. Possibilidade de ocorrência de dano inverso. Agravo regimental a que se nega provimento." (STF, STA 175-AgR/CE, Pleno, Rel. Min. Gilmar Mendes, j. 17/03/2010, DJe 29/04/2010).
} 
O caso concreto cuidava de um paciente, portador de uma raríssima doença - doença de Niemann-Pick Tipo C - que necessitava do medicamento Zavesca, não registrado na Anvisa. A ação judicial pretendia a condenação solidária da União, do Estado do Ceará e do Município de Fortaleza ao fornecimento do fármaco, cujo custo mensal estava estimado em cerca de R $\$ 52$ mil. O Tribunal Regional Federal da $5^{\text {a }}$ Região concedeu antecipação de tutela, a fim de que fosse imediatamente fornecido o medicamento. Aviado pedido de suspensão da tutela antecipada à Presidência do STF, foi mantida a posição do Tribunal Regional. A União agravou da decisão e levou a questão ao Plenário da corte.

Em síntese, a União expendeu os seguintes argumentos: (a) violação do princípio da separação dos poderes, em razão da interferência judiciária nas políticas públicas da Administração Pública; (b) inexistência de previsão normativa que disponha sobre a solidariedade entre integrantes do SUS, o que levaria ao polo passivo da ação apenas o ente responsável pela dispensação do medicamento; e (c) grave lesão às finanças e saúde públicas e possibilidade de efeito multiplicador.

Como se percebe, a defesa deduzida pela União permitiu ao tribunal discutir grande parte das teses da Fazenda Pública, dando ao julgado a possibilidade de decidir algumas questões recorrentes na prática judiciária brasileira.

Pois bem. Na ocasião, as balizas indicadas no voto do ministro Gilmar Mendes foram acompanhadas à unanimidade pelo plenário da corte. Ei-las, de forma sistematizada e sintética ${ }^{47}$ :

(a) se existe a política pública e a Administração Pública não fornece a prestação material ali prevista, o cidadão tem direito subjetivo a obtê-la. Neste caso, o Poder Judiciário não está criando política pública, mas apenas determinando seu cumprimento;

(b) se não existe política pública que abranja a prestação material requerida, deve-se verificar o motivo da falta de fornecimento, que pode ser: (i) uma omissão legislativa ou administrativa; (ii) uma decisão administrativa de não fornecê-la ou (iii) a vedação legal expressa à sua dispensação. De qualquer forma, é vedado à Administração Pública fornecer prestação material que não possua registro na Anvisa, por força de lei ${ }^{48}$;

\footnotetext{
${ }^{47}$ Os fundamentos do voto do Ministro Gilmar Mendes, relator do AgRg na STA 175/CE, também estão sintetizados em doutrina, em uma das obras de referência deste trabalho. (MENDES, Gilmar Ferreira; BRANCO, Paulo Gustavo Gonet. op. cit., p. 715-719).

48 "Art. 12 - Nenhum dos produtos de que trata esta Lei, inclusive os importados, poderá ser industrializado, exposto à venda ou entregue ao consumo antes de registrado no Ministério da Saúde". BRASIL. Lei n. 6.360 de 23 de setembro de 1976. Dispõe sobre a Vigilância Sanitária a que ficam sujeitos os Medicamentos, as Drogas, os Insumos Farmacêuticos e Correlatos, Cosméticos, Saneantes e Outros Produtos, e dá outras Providências. Disponivel em: <http://www.planalto.gov.br/ccivil_03/leis/L6360.htm>. Acesso em: 10 jun. 2015.
} 
(c) outro dado a ser considerado é a motivação para o não fornecimento de determinada ação de saúde pelo SUS. Há situações em que se ajuíza a ação com objetivo de garantir prestação de saúde que o SUS decidiu não custear, por entender que inexistem evidências científicas suficientes para autorizar sua inclusão. Nesse caso, há duas hipóteses a se considerar: (i) o SUS fornece tratamento alternativo, mas não adequado a determinado paciente. Esta situação exige cautela, pois os protocolos clínicos e diretrizes terapêuticas adotados representam um consenso científico sobre a condução de determinada doença. São instrumentos das políticas públicas de saúde, que visam à universalidade e à igualdade, principalmente porque equalizam as demandas da coletividade com a escassez dos recursos públicos para atendê-las. Assim, como regra, deve ser privilegiado o tratamento fornecido pelo SUS, salvo em situações excepcionalíssimas, nas quais restar assentada a ineficácia ou impropriedade da política pública existente. (ii) O SUS não fornece nenhuma prestação material para determinada doença. Neste caso, é possível que existam tratamentos experimentais, que não têm ainda comprovação científica de sua eficácia. Tais drogas, porque ainda não aprovadas pelas autoridades sanitárias, não podem sequer ser comercializadas e, menos ainda, fornecidas pelo SUS. Outra hipótese é a existência de novos tratamentos, ainda não incorporados aos protocolos clínicos e diretrizes terapêuticas do SUS. É cediço que a burocracia administrativa pode eventualmente dificultar a incorporação desses novos tratamentos ao sistema público. Assim, não se afasta a possibilidade de que a omissão administrativa seja objeto de impugnação judicial.

Apesar das balizas com nítido teor normativo, em razão de seu alcance abstrato e genérico, no caso concreto discutido no precedente, o STF concluiu que as provas juntadas aos autos atestaram a eficácia do medicamento e, por outro lado, não restou comprovada a grave lesão à ordem, à saúde e à economia públicas, mantendo a tutela antecipada até então deferida.

Esse precedente do STF tem especial significado, na medida em que incorpora grande parte das ponderações realizadas ao longo dos debates firmados nas audiências públicas de março e abril de 2009. Com efeito, os apontamentos trazidos à baila pelos ministros, pelo aprofundamento do tema, certamente representam importante baliza para todos os demais órgãos do Poder Judiciário, na rotina diária de enfrentamento das milhares de ações judiciais que discutem o direito à saúde.

Outrossim, percebe-se que o julgado cuidou de abordar, de forma sistemática, algumas questões relevantes para o deslinde dos vários pedidos formulados nas ações judiciais, em especial as concernentes à falta de registro de medicamentos na Anvisa, à ausência de estudos científicos conclusivos sobre determinadas prestações materiais etc. 
Além disso, é bastante relevante o fato de a corte ter destacado que, no caso concreto, ficou provada a eficácia do medicamento no tratamento da doença, ainda que sem o registro na Anvisa. Tal entendimento abre possibilidade de que uma ação judicial permita a condenação do poder público ao fornecimento de prestações materiais em saúde, desde que o autor se desincumba do ônus de provar a eficácia concreta do objeto pretendido no tratamento de sua enfermidade.

Em suma, o caso resolvido pelo STF é um retrato fiel do que este trabalho qualifica como terceira fase da evolução jurisprudencial dos tribunais superiores, ou seja, quando se chegou mais próximo do ponto de equilíbrio existente entre as infinitas demandas dos usuários e a necessidade de organização e racionalidade do SUS ${ }^{49}$.

\section{Considerações finais}

No cenário jurídico delineado pela Constituição Federal de 1988, a judicialização do direito à saúde tem sido uma das questões mais importantes da administração judiciária brasileira. O grande número de ações sobre o assunto, ajuizadas principalmente na última década, demonstra a necessidade de se discutirem e adotarem parâmetros racionais para que a tutela jurisdicional seja entregue ao cidadão de forma mais célere e justa possível.

Por outro lado, o aumento gradual da judicialização da saúde tem gerado relevante impacto no orçamento público, em razão das decisões judiciais que condenam o poder público ao fornecimento de diversas prestações materiais de alto custo.

O STF e o STJ, chamados a responder sobre essas demandas, oscilaram sua jurisprudência entre dois extremos até chegarem, atualmente, a um ponto de equilíbrio. Nos primeiros julgados, as duas cortes firmaram interpretação que inviabilizava a reclamação judicial do direito à saúde, sob o argumento de que as políticas públicas sanitárias estariam submetidas a critérios de conveniência e oportunidade da Administração Pública. Depois, passou-se a uma posição extremamente permissiva, na qual praticamente todas as prestações pleiteadas eram concedidas, sob a ótica da necessidade de se resguardar a dignidade da pessoa humana.

\footnotetext{
${ }^{49}$ Esta é a linha de entendimento adotada, também, por Mariana Filchtiner Figueiredo: “A fundamentalidade material e formal dos direitos sociais, contudo, não significa a absolutização, nem tampouco uma eficácia ilimitada desses direitos. A incidência de direitos fundamentais de terceiros; a escassez real dos recursos financeiros e fáticos disponíveis à consecução dos direitos sociais; a adequação às regras constitucionais de distribuição do poder, horizontal e verticalmente, ou seja, os princípios da separação dos Poderes e da federação; as discriminações positivas a que se propõem os direitos sociais, enquanto direitos dirigidos à superação, no 'ponto de chegada', das diferenças fáticas que separam as pessoas; e a necessidade de concordância harmônica, proporcional e razoável entre todas essas grandezas jurídica e constitucionalmente relevantes, enfim, antepõem-se como objeções à efetivação dos direitos sociais". (FIGUEIREDO, Mariana Filchtiner. Direito fundamental à saúde: parâmetros para sua eficácia e efetividade. Porto Alegre: Livraria do Advogado, 2007. p. 222).
} 
Atualmente, a jurisprudência dominante nos dois tribunais superiores tem observado os critérios postos pelas políticas públicas sanitárias estabelecidas pelo Estado brasileiro, sem se olvidar de conceder tutelas jurisdicionais especiais para situações específicas e graves, ponderando no caso concreto o direito do cidadão a ter providas suas necessidades sanitárias e os critérios da Administração Pública para o fornecimento das prestações materiais em saúde.

\section{Referências}

AMARAL, Gustavo. Saúde direito de todos, saúde direito de cada um: reflexões para a transição da práxis judiciária. In NOBRE, Milton Augusto de Brito; SILVA, Ricardo Augusto Dias da (Coords.). O CNJ e os desafios da efetivação do direito à saúde. Belo Horizonte: Fórum, 2011.

BOTELHO, Ramon Fagundes. A judicialização do direito à saúde. Curitiba: Juruá, 2011.

CONSELHO NACIONAL DE JUSTIÇA. Disponível em: <http://www.cnj.jus.br/images/ programas/forumdasaude/relatorio_atualizado_da_resolucao107.pdf $>$. Acesso em: 12 out. 2012.

CUNHA, Leonardo José Carneiro da. A Fazenda Pública em juízo. 8. ed. São Paulo: Dialética, 2010.

CUNHA JÚNIOR, Dirley. Curso de direito constitucional. 2. ed. Salvador: Juspodivm, 2008.

DAVIES, Ana Carolina Izidório. Saúde pública e seus limites constitucionais. São Paulo: Verbatim, 2012.

DELDUQUE, Maria Célia; MARQUES, Sílvia Badim; CIARLINI, Álvaro. Judicialização das políticas públicas de saúde no Brasil. In: ALVES, Sandra Mara Campos; Dedulque, Maria Célia; Dino Neto, Nicolau (Orgs.). Direito sanitário em perspectiva. Brasília: ESMPU: Fiocruz, 2013. v. 2.

FIGUEIREDO, Mariana Filchtiner. Direito fundamental à saúde: parâmetros para sua eficácia e efetividade. Porto Alegre: Livraria do Advogado, 2007.

LEAL, Rogério Gesta. Condições e possibilidades eficaciais dos direitos fundamentais sociais: os desafios do Poder Judiciário no Brasil. Porto Alegre: Livraria do Advogado, 2009.

LEITE, Rodrigo; JOSINO, Miguel. Análise das divergências jurisprudenciais no STF e STJ. Salvador: JusPodivm, 2011.

LOPES, José Reinaldo de Lima. O direito subjetivo e direitos sociais: o dilema do Judiciário no Estado Social de Direito. In FARIA, José Eduardo (Org.). Direitos humanos, direitos sociais e justiça. São Paulo: Malheiros Ed., 2010.

MENDES, Gilmar Ferreira; BRANCO, Paulo Gustavo Gonet. Curso de direito constitucional. 6. ed. São Paulo: Saraiva, 2011.

MOREIRA, Alinie da Matta. As restrições em torno da reserva do possível: uma análise crítica. Belo Horizonte: Fórum, 2011. 
Jurisprudência em direito à saúde rumo à racionalidade

PORTAL da Saúde. Disponível em: <http://portalsaude.saude.gov.br/portalsaude/arquivos/ pdf/2012/Dez/17/EVOLUcaOGASTOS.pdf>. Acesso em: 27 mar. 2013.

ROSAS, Roberto. Direito sumular (comentários às súmulas do Supremo Tribunal Federal e do Superior Tribunal de Justiça). 13. ed. São Paulo: Malheiros Ed., 2006.

SALAZAR, Andrea Lazzarini; GROU, Karina Bozola. A defesa da saúde em juízo: teoria e prática. São Paulo: Verbatim, 2009.

SUPREMO TRIBUNAL FEDERAL. Despacho de Convocação de Audiência Pública, de 5 de março de 2009. Disponível em: <http://www.stf.jus.br/arquivo/cms/processoAudienciaPublicaSaude/ anexo/Despacho_Convocatorio.pdf>. Acesso em: 09 out. 2012.

Otávio Balestra Neto - Mestre em Direito, Relações Internacionais e Desenvolvimento pela Pontifícia Universidade de Goiás; especialista em Direito Civil e Direito Processual Civil pela Uni-Anhanguera; graduado em Medicina pela Universidade Federal de Goiás. Procurador da República em Rio Verde. Rio Verde/GO, Brasil. E-mail: balestraneto@msn.com. 